\title{
Pengaruh penggunaan helm terhadap cedera kraniofasial berdasarkan skor FISS dan CT Marshall
}

\author{
${ }^{1}$ Hendrik Mengga, ${ }^{2}$ Mendy Hatibie, ${ }^{3}$ Eko Prasetyo, ${ }^{3}$ Maximillian Ch. Oley
}

\author{
${ }^{1}$ Program Studi Ilmu Bedah Fakultas Kedokteran Universitas Sam Ratulangi Manado \\ ${ }^{2}$ KSM Ilmu Bedah Divisi Bedah Plastik RSUP Prof. Dr. R. D. Kandou Manado \\ ${ }^{3}$ KSM Ilmu Bedah Divisi Bedah Saraf RSUP Prof. Dr. R. D. Kandou Manado \\ Email: surgilicious@gmail.com
}

\begin{abstract}
Helmet can reduce head trauma as well as maxillofacial trauma due to motorcycle accident. This study was aimed to prove the effect of helmet and its type in reducing craniofacial injury. Any intracranial abnormalities were evaluated with the CT Marshall scoring system and maxillofacial abnormalities were evaluated with FISS. This was an analytical comparative study with a cross sectional design. The results showed that there were 72 patients with craniofacial trauma; 59 patients with intracranial abnormalities and 24 patients with maxillofacial abnormalities. There were $43.1 \%$ patients that wore helmet; $31.9 \%$ of them wore open-face helmet. Data were analyzed by using the unpaired t-tests. Based on FISS, the effect of helmet on maxillofacial injury obtained a t-value of $0.787(P=0.217)$ which indicated that there was no difference in FISS scores between patients wearing helmet and not. Based on the CT Marshall scoring system, the effect of helmet on the intracranial injury obtained a t-value of $1.822(P=0.036)$ which indicated that there was a difference in scores between patients wearing helmet and not. This meant that wearing helmets had some influence on the occurence of head injuries. Based on FISS, the impacts of full-face helmet and open-face helmet on maxillofacial injuries obtained a t-value of $1.890(P=0.034)$ which indicated that there was a difference in FISS between the two types of helmets. Based on the CT Marshall scoring system, the impacts of full-face helmet and open-face helmet on intracranial injuries obtained a $\mathrm{t}$-value of $1.714(P=0.049)$ which indicated that there was a difference in CT Marshall scores between the two types of helmets. Conclusion: Helmet and its type, full-face and open-face, had some influence on the occurence of either maxillofacial or intracranial injuries.
\end{abstract}

Keywords: craniofacial injury, motorcycle, helmet

\begin{abstract}
Abstrak: Penggunaan helm dapat mengurangi kejadian trauma kepala dan trauma maksiofasial akibat kecelakaan sepeda motor. Penelitian ini bertujuan untuk membuktikan bahwa pemakaian helm dan tipe helm berperan dalam menurunkan cedera kraniofasial. Abnormalitas intrakranial dievaluasi dengan skoring CT Marshall dan abnormalitas maksilofasial dievaluasi dengan FISS. Jenis penelitian ialah analitik komparatif dengan desain potong lintang. Hasil penelitian mendapatkan 72 pasien dengan trauma kraniofasial; 59 pasien dengan abnormalitas intrakranial dan 24 pasien dengan abnormalitas maksilofasial. Terdapat $43,1 \%$ pasien yang menggunakan helm; 31,9\% menggunakan helm open-face. Data dianalisis menggyunakan uji t tidak berpasangan. Berdasarkan FISS, efek helm terhadap cedera maksilofasial mendapatkan $\mathrm{t}=0,787(P=0,217)$ yag menunjukkan tidak terdapat perbedaan skor antara pasien yang menggunakan dan tidak menggunakan helm. Berdasarkan skoring CT Marshall, efek helm terhadap cedera intrakranial mendapatkan $t=1,822(P=0,036)$ yang menunjukkan terdapat perbedaan skor antara pasien yang menggunakan dan tidak menggunakan helm. Hal ini memperlihatkan bahwa penggunaan helm berpengaruh terhadap kejadian cedera kepala. Berdasarkan FISS, dampak jenis helm full-face dan open-face terhadap cedera maksilofasial mendapatkan $\mathrm{t}=1,890(P=0,034)$ yang menyatakan terdapat
\end{abstract}


perbedaan skor FISS antara pengggunaan kedua jenis helm. Berdasarkan skoring CT Marshall, dampak helm full-face dan open-face terhadap cedera intrakranial mendapatkan $\mathrm{t}=1,714(P=$ 0,049) yang menunjukkan terdapat perbedaan skor CT Marshall antara penggunaan kedua jenis helm. Simpulan: Penggunaan helm dan jenis helm (full-face dan open-face) memengaruhi terjadinya cedera maksilofasial dan intrakranial.

Kata kunci: cedera kraniofasial, sepeda motor, helm

Kraniofasial meliputi bagian kepala dan bagian wajah sedangkan cedera kraniofasial terdiri dari cedera otak akibat trauma dan cedera maksilofasial. Penggunaan istilah ini pertama kali dikemukakan oleh Huxley pada tahun $1855 .^{1}$ Perbandingan laki-laki dan perempuan dalam hal cedera kraniofasial ialah 2,7 : 1, dan yang paling sering mengalami fraktur ialah mandibula (69\%) dengan melibatkan angulus, parasimfisis, korpus, dan kondilus. $^{2}$

Sepeda motor terus berkembang dengan pesat dan merupakan jenis kendaraan bermotor yang paling banyak digunakan terutama oleh kelas ekonomi menengah dan rendah. Sepeda motor juga berperan penting sebagai bagian dari kehidupan sosial di negara kelas atas. ${ }^{3}$

Di Indonesia, jumlah kendaraan bermotor yang meningkat setiap tahunnya dan kelalaian manusia menjadi faktor utama terjadinya peningkatan kecelakaan lalu lintas (KLL). Data Kepolisian RI menyebutkan pada tahun 2012 terjadi 109.038 kasus KLL dengan korban meninggal dunia sebanyak 27.441 orang, dan potensi kerugian sosial ekonomi sekitar Rp 203 triliun - Rp 217 triliun per tahun (2,9\%-3,1\% dari pendapatan domestik bruto/PDB Indonesia). Pada tahun 2011, terjadi KLL sebanyak 109.776 kasus, dengan korban meninggal sebanyak 31.185 orang. ${ }^{4}$

Berdasarkan data dari Direktorat Jenderal Perhubungan Darat tahun 2013, angka KLL di Provinsi Sulawesi Utara saat ini masih cukup tinggi. Sebagaimana dilaporkan dalam data Kepolisian RI jumlah KLL mencapai 1.535 kejadian. Dari jumlah korban KLL sebanyak 2.491 orang, 328 orang diantaranya meniggal dunia, 822 orang mengalami luka berat,dan 1.341 luka ringan. ${ }^{5}$ Tingginya angka kecelakaan ini diakibatkan ketidak seimbangan antara permintaan dan penawaran dalam bidang transportasi, perkembangan kendaraan bermotor sekitar $10 \%$ pertahun yang hanya diikuti oleh kurang $<1 \%$ pertumbuhan infrastruktur. ${ }^{6}$

Pola cedera maksilofasial pada KLL motor paling banyak pada bagian lower face $(46,9 \%)$, diikuti bagian midface $(25,7 \%)$, kombinasi bagian lower face dan midface (15\%), sedangkan bagian yang lain hanya $12,4 \%{ }^{?}$

Pada kecelakaan motor dapat terjadi cedera kepala dan diperkirakan menyebabkan kematian sekitar 50\% dari kejadian ini. Hampir sepertiga dari seluruh korban hanya mengalami cedera kepala akan tetapi dalam setiap penelitian hampir sekitar $90 \%$ cedera kepala ini terjadi bersamaan dengan cedera organ lain. Dari data tersebut diperkirakan hanya sekitar $50 \%$ pengendara motor yang menggunakan helm.

Jika pengendara motor menggunakan helm saat terjadinya kecelakaan maka risiko kematian bisa berkurang sekitar $42 \%$ sedangkan pada pengendara tanpa helm mempunyai risiko cedera kepala dan kematian sekitar 3,1 kali lipat. Hasil penelitian juga menunjukkan adanya pengaruh kebijakan hukum yang mengatur penggunaan helm dalam berkendara bisa menurunkan angka cedera. ${ }^{9}$ Penyebab cedera otak akibat trauma (COT) yang sering ialah terjatuh sebanyak $28 \%$, kecelakaan kendaraan bermotor sebanyak $20 \%$, pejalan kaki yang tertabrak sebanyak $19 \%$, dan kekerasan sebanyak $11 \%$. COT mempunyai distribusi usia bimodal yakni pada usia 0-4 tahun dan usia 15-19 tahun. ${ }^{10}$

Kecenderungan akan berkurangnya mortalitas dan terjadinya perbaikan luaran dari COT merupakan dampak dari penggunaan protokol berdasarkan 
evidence-based dalam melakukan monitor dan pemeliharaan perfusi serebral. ${ }^{11}$

Berdasarkan data Kepolisian Republik Indonesia di tiga provinsi, kecelakaan yang berakibat fatal $61 \%$ dialami oleh pengendara sepeda motor. ${ }^{6}$ Studi Conrad et al. ${ }^{12}$ menyatakan bahwa di wilayah Yogyakarta sekitarnya terdapat $30 \%$ pengendara sepeda motor yang mengalami KLL dan $26 \%$ harus dirawat di rumah sakit. Kematian dalam kecelakaan motor berkaitan dengan objek yang ditabrak (pohon, rambu lalu lintas, pembatas jalan atau kendaraan lain), perilaku berisiko (alkohol dan ugal-ugalan), juga dengan tingkat kecepatan. Cedera kepala sering terjadi khususnya pada pengendara yang tidak memakai helm. ${ }^{13}$ Penelitian oleh Czerwinzki et al. ${ }^{14}$ mendapatkan bahwa penderita dengan fraktur mandibula $40 \%$ berhubungan dengan cedera kepala dan $34 \%$ berhubungan dengan cedera intrakranial. Sejak penemuan helm sekitar tahun 1935 oleh Hugh Cairns terdapat penurunan cedera kepala yang nyata akibat kecelakaan motor. ${ }^{15}$

Pemakaian helm efektif dalam mengurangi cedera maksilofasial pada suatu tabrakan sepeda motor. Bila dibandingkan dengan yang menggunakan helm, pengendara motor yang tidak menggunakan helm berpeluang tiga kali lipat untuk menderita fraktur tulang wajah. Penggunaan alkohol juga mempunyai hubungan dengan tidak menggunakan helm. ${ }^{16}$ Selain efektif mencegah cedera kepala, penggunaan helm juga dapat menurunkan risiko terjadinya cedera tulang vertebra servikal pada KLL. ${ }^{17}$

Pada kecelakaan motor dan sepeda terdapat dua prinsip mekanisme terjadinya cedera otak yang utama, yakni melalui kontak langsung serta melalui akselerasi dan deselerasi. Pada mekanisme akselerasi dan deselerasi, otak dengan massa yang dimilikinya tetap maju kedepan hingga membentur bagian dalam tengkorak kemudian terpantul ke bagian belakang tengkorak. Pemakaian helm dapat bekerja untuk mengurangi mekanisme ini. ${ }^{18}$

Di Indonesia sendiri terdapat standarisasi nasional dalam penggunaan helm sebagai upaya untuk mengurangi resiko cedera kepala. Standarisasi ini menetapkan spesifikasi teknis untuk helm pelindung yang digunakan oleh pengendara dan penumpang kendaraan bermotor roda dua, meliputi klasifikasi helm standar terbuka (open-face) dan helm standar tertutup (full-face). ${ }^{19}$

Regulasi mengenai pemakaian helm di Indonesia terdapat pada UU Lalu Lintas Nomor 22 Tahun 2009 yang menggantikan UU Nomor 14 Tahun 1992 dan mulai efektif dalam bulan Januari 2010. Regulasi ini mengatur pemakaian helm standar yang sesuai Standar Nasional Indonesia (SNI). Pemakaian helm ini diatur dalam pasal 57 ayat 2 dan pasal 106 ayat 8. Sanksi bagi pelanggar aturan ini, pidana kurungan paling lama satu bulan atau denda paling banyak Rp 250.000 (Pasal 291). ${ }^{20}$

COT banyak dijumpai pada pengendara sepeda motor dengan fraktur pada tulang wajah bagian atas. Secara dramatis fraktur tulang wajah yang disertai fraktur tulang tengkorak meningkatkan risiko untuk terjadinya COT. Karena fraktur fasial sangat dikaitkan dengan COT pada penumpang yang menggunakan helm, disarankan untuk skrining cedera kepala walau dengan status pemakaian helm. ${ }^{21}$

Penderita dengan helm tipe open face lebih signifikan untuk mengalami cedera kepala dan leher yang serius terutama kontusio serebri jika dibandingkan dengan penderita lain yang menggunakan helm tipe full-face. $^{22}$

Skor facial injury severity score (FISS) diperkenalkan oleh Bagheri et al. ${ }^{23}$ pada tahun 2006. Pada sistem skoring ini setiap tempat patah tulang dan luka robek mendapatkan poin untuk ditambahkan sebagai skor akhir. Penelitian Bagheri sendiri dengan total pasien 247 orang mendapatkan FISS berkorelasi dengan total biaya operasi dan lama rawat inap. ${ }^{23}$ Walaupun sistem skoring ini telah banyak ditampilkan dalam berbagai publikasi tetapi belum digunakan oleh banyak klinisi karena mungkin belum mengetahui keuntungannya. 
Marshall computed tomography system (CT Marshall) adalah sistem klasifikasi neuroimaging yang paling luas digunakan dalam COT. Kegunaanya penting sebagai suatu variabel prognostik yang independen berdasarkan temuan-temuan pada CT scan, termasuk dalam keadaan daripada sisterna, pergeseran midline, adanya lesi-lesi lokal yang membedakan penderita dalam enam kelompok yang berbeda. ${ }^{24}$

Penelitian mengenai hubungan antara fraktur tulang wajah dengan lesi intrakranial oleh Tanuhendrata et al. ${ }^{25}$ di Manado melaporkan adanya hubungan bermakna dimana semakin berat derajat fraktur tulang wajah semakin besar pula kemungkinan terjadinya lesi intracranial, dan fraktur tulang wajah bagian atas merupakan risiko paling besar untuk terjadinya kelainan intrakranial.

Suatu tinjauan Cochrane yang dilakukan oleh Liu et al. ${ }^{26}$ mengenai efektivitas helm dalam mencegah cedera kepala dan juga cedera wajah menyimpulkan bahwa penelitian selama ini kualitasnya rendah ditinjau dari segi metodologi karena umumnya menggunakan desain potong lintang dan juga terdapat banyak bias dalam penelitian yang diakibatkan oleh masalah etis yang akan muncul bila penelitian dibuat dalam randomized trial.

Komang et al. ${ }^{27}$ melakukan penelitian mengenai efektivitas penggunaan helm pada pengendara sepeda motor dalam mencegah cedera kepala di Manado. Hasil penelitian tersebut mendapatkan penderita cedera kepala sedang dan berat lebih banyak terjadi pada pengendara sepeda motor yang tidak menggunakan helm, yaitu cedera kepala sedang 10,2\% dan cedera kepala berat 20,4\%. Komang et al. menyimpulkan bahwa pengendara sepeda motor yang tidak menggunakan helm akan mengalami cedera kepala sedang dan berat, kemungkinannya dua kali lebih sering dibanding dengan pengendara yang menggunakan helm.

Selama ini dampak mengenai penggunaan helm pada cedera kepala telah banyak diketahui tetapi dampaknya pada cedera maksilofasial belum didokumentasikan dengan baik. ${ }^{9}$ Juga belum pernah dilakukan penelitian mengenai pengaruh penggunaan helm dalam mencegah cedera kraniofasial secara keseluruhan.

\section{METODE PENELITIAN}

Penelitian ini dilakukan di RSUP Prof. Dr. R. D Kandou dan RS jejaring sejak bulan Mei 2016 hingga Desember 2016. Jenis penelitian ialah analitik komparatif dengan desain potong lintang

Penderita yang datang ke Instalasi Gawat Darurat (IGD) Bedah akibat cedera kraniofasial, tetap menjalani prosedur penanganan sesuai prinsip ATLS. Pada secondary survey dilakukan pemeriksaan fisik yang lebih teliti terhadap cedera pada kepala dan wajah termasuk pemeriksaan tulang wajah. Bila secara klinis ditemukan atau pun persangkaan adanya fraktur tulang wajah dan cedera kepala, dilakukan pemeriksaan radiologik $C T$ Scan 3D maksilofasial dan $C T$ scan kepala, kemudian dievaluasi dengan CT Marshall dan skor FISS. Dilakukan anamnesis kembali mengenai riwayat pemakaian helm, jenis helm yang dipakai, dan apakah terkunci atau tidak.

Data yang diperoleh ditabulasi dan diuji kemaknaannya dengan uji $X^{2}$ menggunakan program SPSS 22.0

\section{HASIL PENELITIAN}

Dalam penelitian ini, dievaluasi sebanyak 72 pasien trauma maksilofasial yang datang ke IGD Bedah RSUP Prof. Dr. R. D. Kandou Manado dan RS jejaring yang memenuhi kriteria inklusi, terdiri dari 59 laki-laki dan 13 perempuan.

Dari keseluruhan pasien tersebut yang mengalami kelainan intrakranial sebanyak 59 orang, dan kelainan yang paling banyak ditemukan pada $C T$ scan ialah gambaran epidural hemorrhage (EDH), intracranial hemorrhage (ICH), dan ICH yang disertai kelainan intrakranial lain sebanyak $22,2 \%$, 19,4\% dan 9,7\% secara berturut.

Pasien yang mengalami kelainan maksilofasial sebanyak 24 orang dari total pasien. Jenis kelainan yang didapatkan dari 
gambaran CT Scan rekonstruksi 3D ialah fraktur zygoma sebanyak $9,7 \%$ dan fraktur tulang frontal serta laserasi $>10 \mathrm{~cm}$ dengan frekuensi yang sama yakni 5,6\%.

Dari total 72 pasien terdapat 41 orang $(56,9 \%)$ dengan riwayat tidak menggunakan helm dan 31 orang $(43,1 \%)$ dengan riwayat menggunakan helm; $23(31,9 \%)$ di antaranya menggunakan helm tipe openface dan $8(11,1 \%)$ yang memakai tipe fullface.

Kelainan intrakranial ditemukan pada 35 orang $(85,4 \%)$ dari total 41 pasien yang tidak menggunakan helm saat kecelakaan, dan 24 orang $(77,4 \%)$ dari total 31 pasien yang menggunakan helm saat kecelakaan. Hasil uji $\mathrm{X}^{2}$ diperoleh $\mathrm{X}^{2}=0,753$ dengan $P$ $=0,192$, yang menyatakan tidak terdapat hubungan antara penggunaan helm dengan kejadian kelainan intrakranial (Tabel 1).

Tabel 1. Tabulasi silang antara penggunaan helm dan kelainan intrakranial

\begin{tabular}{cccc}
\hline \multirow{2}{*}{$\begin{array}{c}\text { Pakai } \\
\text { helm }\end{array}$} & \multicolumn{2}{c}{ Kelainan } \\
intrakranial & \multirow{2}{*}{ Jumlah } \\
\cline { 2 - 3 } & Tidak & Ada & \\
\hline \multirow{2}{*}{ Tidak } & 6 & 35 & \multirow{2}{*}{41} \\
& $(14,6 \%)$ & $(85,4 \%)$ & \\
Ya & 7 & 24 & 31 \\
Jumlah & $(22,6 \%)$ & $(77,4 \%)$ & \\
$\mathrm{X}^{2}=0,753(P=0,192)$ & 59 & 72 \\
\hline
\end{tabular}

Hasil uji t tidak berpasangan terhadap skor FISS mendapatkan t $=0,787$ dengan $P$ $=0,217$, yang menyatakan tidak terdapat perbedaan skor FISS antara pasien yang menggunakan helm dan tidak, yang berarti tidak terdapat pengaruh pemakaian helm terhadap cedera maksilofasial (Tabel 2).

Tabel 2. Hasil uji cedera maksilofasial berdasarkan skor FISS

\begin{tabular}{ccccc}
\hline $\begin{array}{c}\text { Pakai } \\
\text { helm }\end{array}$ & Rerata & SB & t & Kemaknaan \\
\hline Tidak & 1,46 & 2,693 & 0,787 & $P=0,217$ \\
Ya & 1,03 & 1,643 & & \\
\hline \multicolumn{2}{l}{ SB = Simpangan baku } & & &
\end{tabular}

Hasil uji t tidak berpasangan terhadap skor CT Marshall mendapatkan $\mathrm{t}=1,822$ dengan $P=0,036$ yang menyatakan terdapat perbedaan cedera intrakranial menurut skor CT Marshall antara pasien yang menggunakan helm dan tidak, yang berarti terdapat pengaruh pemakaian helm terhadap cedera kepala (Tabel 3).

Tabel 3. Hasil uji cedera intrakranial yang diukur dengan CT Marshall

\begin{tabular}{ccccc}
\hline $\begin{array}{c}\text { Pakai } \\
\text { helm }\end{array}$ & Rerata & SB & t & Kemaknaan \\
\hline Tidak & 3,10 & 1,562 & & \\
Ya & 2,45 & 1,387 & 1,822 & $P=0,036$ \\
\hline SB = Simpangan baku & & &
\end{tabular}

Hasil uji t tidak berpasangan terhadap skor FISS dan tipe helm mendapatkan $\mathrm{t}=$ 1,890 dengan $P=0,034$, yang menyatakan terdapat perbedaan cedera maksilofasial menurut skor FISS antara pasien yang menggunakan helm full-face dan open-face (Tabel 4).

Tabel 4. Hasil uji perbedaan skor FISS berdasarkan tipe helm

\begin{tabular}{ccccc}
\hline $\begin{array}{l}\text { Jenis } \\
\text { helm }\end{array}$ & Rerata & SB & t & Kemaknaan \\
\hline $\begin{array}{l}\text { Open } \\
\text { face }\end{array}$ & 1,35 & 1,799 & & \\
$\begin{array}{l}\text { Full } \\
\text { face }\end{array}$ & 0,13 & 0,354 & 1,890 & $P=0,034$ \\
\hline
\end{tabular}

Hasil uji t tidak berpasangan terhadap skor CT Marshall dan tipe helm mendapatkan $\mathrm{t}=1,714$ dengan $P=0,049$, yang menyatakan terdapat perbedaan cedera maksilofasial menurut skor CT Marshall antara pasien yang menggunakan helm full-face dan open-face (Tabel 5).

Tabel 5. Hasil uji perbedaan skor CT Marshall berdasarkan tipe helm

\begin{tabular}{|c|c|c|c|c|}
\hline $\begin{array}{l}\text { Jenis } \\
\text { helm }\end{array}$ & Rerata & SB & $\mathbf{t}$ & Kemaknaan \\
\hline $\begin{array}{l}\text { Open } \\
\text { face }\end{array}$ & 2,70 & 1,490 & \multirow[b]{2}{*}{1,714} & \multirow[b]{2}{*}{$P=0,049$} \\
\hline $\begin{array}{l}\text { Full } \\
\text { face }\end{array}$ & 1,75 & 0,707 & & \\
\hline
\end{tabular}




\section{BAHASAN}

Penderita yang mengalami kecelakaan sepeda motor tanpa menggunakan helm berpeluang sangat besar untuk mengalami cedera maksilofasial. Seperti halnya cedera otak akibat trauma, hal ini juga menyebabkan angka kematian dan kecacatan pada populasi usia muda. Penggunaan helm dapat mengurangi terjadinya hal tersebut. ${ }^{28}$

Pada penelitian ini didapatkan angka kepatuhan pemakaian helm hanya $43,1 \%$. Data observasional yang dilaporkan oleh Condrad et al. ${ }^{12}$ di Indonesia mendapatkan angka kepatuhan pemakaian helm $89 \%$. Perbedaan kepatuhan tidak memakai helm disebabkan pemakaian helm yang rendah pada malam dari juga berkaitan dengan faktor pengaruh alkohol saat berkendara. Penelitian observasi di pinggiran jalan oleh Peek-asa et al. ${ }^{29}$ tahun 1998 di Los Angeles melaporkan kepatuhan pemakaian helm $99 \%$ tetapi terdapat $15,5 \%$ yang menggunakan helm tidak standar. Disebutkan juga bahwa angka kepatuhan penggunaan helm lebih rendah pada akhir pekan dan juga pada malam hari. Angka kepatuhan penggunaan helm dipengaruhi oleh ada tidaknya aturan penggunaan helm di negara tersebut. Di Indonesia regulasi mengenai pemakaian helm di Indonesia terdapat dalam UU Lalu Lintas Nomor 22 Tahun 2009 yang menggantikan UU Nomor 14 Tahun 1992 dan mulai efektif dalam bulan januari $2010 .^{20}$

Pemberlakuan aturan mengenai penggunaan helm diberlakukan karena dampaknya dapat menurunkan angka trauma. Penelitian oleh Houston ${ }^{30}$ tahun 2007 mendapatkan penurunan $31 \%$ trauma pada kelompok usia 15-20 tahun dengan adanya aturan pemakaian helm secara menyeluruh. Meskipun telah diberlakukan aturan penggunaan helm, terdapat sekitar $41-69 \%$ pengendara motor tidak menggunakan helm di negara dengan ekonomi rendah sampai menegah. ${ }^{31}$

Jenis helm yang paling banyak didapatkan di dalam penelitian ini ialah open-face yaitu sebanyak $31,9 \%$ dari total $43,1 \%$ pasien yang menggunakan helm.
Penggunaan helm yang tidak standar dipengaruhi oleh hal-hal seperti biaya, berat helm, batasan pendengaran dan penglihatan, peningkatan suhu sekitar, maupun karena kebiasaan setempat. ${ }^{32}$ Helm harus mempunyai sistem ventilasi yang baik sehingga pengguna tidak merasakan panas pada permukaan kepala. Hal ini harus juga diperhatikan agar tidak mengganggu konstruksi helm itu sendiri sehingga fungsi proteksinya tetap ada. ${ }^{33}$ Dalam suatu penelitian yang dilakukan oleh Ramli et al. $^{34}$ di Malaysia, angka penggunaan helm jenis open-face sebesar $76,2 \%$ sedangkan jenis full-face sebesar $1,2 \%$.

Hasil penelitian ini masih mendapatkan kelainan intrakranial pada $77,4 \%$ pasien yang menggunakan helm. Hal ini dapat diakibatkan oleh beberapa faktor diantaranya: pengendara motor memakai helm secara tidak tepat atau bahan helm yang tidak sesuai standar. Fiksasi helm yang baik lebih penting dibandingkan jenis helm dalam melindungi pengendara motor. Helm yang telepas saat kecelakaan mempunyai peluang lima kali lebih besar untuk mengalami cedera kepala dan empat kali lebih besar untuk mengalami cedera kepala berat. ${ }^{34}$

Selain ketertiban pemakaian helm, cara pemakaian pun turut berperan dalam mencapai perlindungan maksimal dari helm. Dalam suatu penelitian di Malaysia, dari 5000 pengendara motor terdapat hanya $54 \%$ yang menggunakan helm secara benar, $21 \%$ tidak menggunakan dengan benar, dan $24 \%$ tidak menggunakan helm. Seluruh pengedara yang tidak menggunakan helm ialah berusia muda, dan yang tidak mendapatkan pendidikan formal cenderung untuk memakai helm dengan tepat. ${ }^{35}$

Thai et al. ${ }^{36}$ melaporkan bahwa tidak didapatkan hubungan antara ketepatan ukuran antara helm dan kepala walaupun hal tersebut akan meningkatkan resiko terlepasnya helm sewaktu kecelakaan. Ketidaksesuaian ukuran helm dan kepala berdasarkan ukuran yang direkomendasikan tidak tepat dengan ukuran pada 
sebagian besar populasi hal ini karena terdapat perbedaan bentuk anatomi kepala.

Toleransi cedera kepala pada pemakaian helm mempunyai beberapa prediktor yang telah diketahui diantaranya linear head (brain) acceleration (PLA), head injury criteria (HIC), beberapa kriteria akselerasi yang lain dan rotational acceleration of the brain. Yang paling banyak dipakai di helm standar sekarang yakni PLA dan HIC, dan PLA saja. ${ }^{37}$

Dalam penelitian ini tidak didapatkan pengaruh penggunaan helm terhadap adanya cedera maksilofasial yang dapat disebabkan karena sebagian besar pengendara motor memakai jenis helm half-face yang tidak memroteksi wajah bagian tengah dan bawah. Hasil ini sejalan dengan yang dikemukakan oleh Ramli et al. $^{38}$ yaitu bahwa jenis helm, kondisi fiksasi helm saat kejadian, dan berat tidaknya kerusakan visor helm berkaitan dengan trauma pada maksilofasial. Perlindungan dari suatu helm tergantung pada semakin besarnya area yang dicakup maka semakin efektif pula helm tersebut; dengan kata lain helm jenis full-face lebih superior dalam memberikan perlindungan wajah terutama untuk bagian wajah bagian bawah. Juga dari segi desain, helm jenis full-face tidak mudah terlepas saat tabrakan. ${ }^{39}$

Visor dari helm juga berkaitan dengan trauma fasial karena visor ini tidak di desain untuk menyerap dan mendistribusi energi saat tubrukan. Pelindung yang terbuat dari bahan polikarbonat ini secara umum hanya memberi perlindungan wajah dari debu dan partikel kecil di jalan raya, sehingga bagian protektif dari helm ialah desainnya dan bukan ada tidaknya visor, bahkan fenomena seperti pecahnya visor dapat menyebabkan laserasi dari wajah sendiri. ${ }^{38}$ Laserasi pada wajah merupakan salah satu komponen dalam penilaian FISS sehingga hal ini bisa merupakan salah satu faktor yang menyebabkan tidak adanya pengaruh antara pemakaian helm dan cedera maksilofasial.

Dalam penelitian ini didapatkan adanya pengaruh penggunaan helm terhadap kejadian cedera kepala. Hal ini sejalan dengan beberapa penelitian sebelumnya. Jenis hematoma yang dapat dihindari dengan penggunaan helm yaitu hematoma epidural yang berkaitan dengan adanya fraktur tengkorak. ${ }^{40}$ Meskipun demikian tetap didapatkan kelainan pada pengendara yang menggunakan helm. Tingginya angka patah tulang bagian samping tengkorak pada pengendara yang menggunakan helm diakibatkan oleh sisi dari tengkorak merupakan daerah yang paling lemah karena pada daerah ini ketebalan tulang paling rendah. Helm yang tersedia kurang dapat memroteksi daerah ini karena kurang tertutupi oleh bagian helm, ketebalan cangkang helm yang tipis di daerah ini, dan bagian helm pada daerah ini tepinya fleksibel dan kurang kaku yang diakibatkan karena kurvatura cangkang yang lebih besar. Selain itu, bagian samping kepala merupakan bagian yang paling sering terbentur dalam kecelakaan motor. $^{37}$

Hitosugi et al. ${ }^{22}$ mendapatkan tidak ada perbedaan beratnya cedera pada kedua kelompok jenis helm bila diukur dengan Abbreviated Injury Scale (AIS). Juga prevalensi terjadinya kelainan intrakranial tidak berbeda hanya saja kontusio jaringan otak lebih banyak didapatkan pada tipe helm open-face $(57,9 \%)$ dibanding tipe helm full-face $(17,6 \%)$. Oleh Erhardt et al. $^{41}$ dikemukakan bahwa helm full-face lebih bisa menghindari cedera kepala dibandingkan dengan helm jenis half-face maupun jenis helm lainnya.

Berdasarkan FISS, pada penelitian ini didapatkan adanya perbedaan antara pasien yang menggunakan helm full-face dan open-face. Hal ini diakibatkan karena helm open-face tidak dapat mencegah trauma pada bagian bawah wajah. Hal ini sejalan dengan yang dikemukakan oleh Lopes et al. $^{42}$ yaitu skor rerata FISS lebih tinggi pada yang tidak menggunakan helm dibandingkan dengan yang menggu-nakan helm full-face tetapi tidak didapatkan perbedaan FISS antara yang tidak menggunakan helm dan yang menggunakan helm open-face. 


\section{SIMPULAN}

Dari hasil penelitian dan bahasan dapat disimpulkan bahwa terdapat pengaruh pemakaian helm dan jenis helm full-face dan open-face terhadap kejadian cedera kepala, baik cedera maksilofasial maupun cedera intrakranial.

\section{DAFTAR PUSTAKA}

1. Huxley TH. The craniofacial apparatus of petromyzon. J Anat Phys. 1876;10(16):411-31.

2. Bamjee Y, Lownie JF, Cleaton-Jones PE, Lownie MA. Maxillofacial injuries in a group of South Africans under 18 years of age. Br J Oral Maxillofac Surg. 1996;34:298-302.

3. De Rome L, Ivers R, Fitzharris M, Du W, Haworth $N$, Heritier $S$, et al. Motorcycle protective clothing: Protection from injury or just the weather? Accid Anal Prev. 2011;43(6):1893-900.

4. Hartanto PIP. Jadilah Pelopor Keselamatan Berlalu lintas dan Budayakan Keselamatan sebagai Kebutuhan. Jakarta: Korlantas Mabes Polri, 2012; p. 2.

5. Direktur Jenderal Perhubungan Darat. Perhubungan darat dalam angka 2013. Jakarta, 2014.

6. Soehodho S. Motorization in Indonesia and its impact to traffic accidents. IATSS Res. 2007;31(2):27-33.

7. Ramli R, Abdul Rahman R, Abdul Rahman N, Abdul Karim F, Krsna Rajandram R, Mohamad MSF, et al. Pattern of maxillofacial injuries in motorcyclists in Malaysia. J Craniofac Surg. 2008;19(2):316-21.

8. MacLeod JB, Digiacomo JC, Tinkoff G. An evidence-based review: helmet efficacy to reduce head injury and mortality in motorcycle crashes: EAST practice management guidelines. $\mathrm{J}$ Trauma. 2010;69(5): 1101-11.

9. Cristina M, Maliska DS, Borba M, Asprino $\mathbf{L}$, Moraes M De, Willian R, et al. Oral and maxillofacial surgery - Helmet and maxillofacial trauma: a 10-year retrospective study. Braz J Oral Sci. 2012;11(2):125-9.

10. Post A, Boro T, Ecklund J. Injury to the brain. In: Mattox K, Moore E,
Feliciano D, editors. Trauma (7th ed). Houston, Texas: McGraw-Hill, 2013; p. 356-7.

11. Surgeons. BTFAA of NSC of N. Guidelines for the Management of Severe Traumatic Brain Injury 3rd Edition. J Neurosurg. 2007;24, Suppl(212):S1106.

12. Conrad P, Bradshaw YS, Lamsudin R, Kasniyah N, Costello C. Helmets, injuries and cultural definitions: Motorcycle injury in urban Indonesia. Accid Anal Prev. 1996;28(2):193-200.

13. Nunn S. Death by motorcycle: Background, behavioral, and situational correlates of fatal motorcycle collisions. J Forensic Sci. 2011;56(2):429-37.

14. Czerwinski M, Parker WL, Chehade A, Williams HB. Identification of mandibular fracture epidemiology in Canada: Enhancing injury prevention and patient evaluation. Can J Plast Surg. 2008;16(1):36-40.

15. Maartens NF, Wills AD, Adams CBT. Lawrence of Arabia, Sir Hugh Cairns, and the origin of motorcycle helmets. Neurosurgery. 2002;50(1):176-9.

16. Johnson RM, McCa-thy MC, Miller SF, Peoples JB. Craniofacial trauma in injured motorcyclists: the impact of helmet usage. J Trauma. 1995;38(6):876.

17. Lam C, Lin M, Chu S, Tsai S, Bai C, Chiu W. The effect of various types of motorcycle helmets on cervical spine injury in head injury patients: A multicenter study in Taiwan. Biomed Res Int. 2015;2015:1-7.

18. World Health Organization. Helmets: A Road safety manual for decision-makers and practictioners. WHO Library Cataloguing in Publication Data, 2006.

19. Badan Standarisasi Nasional. Helm pengendara kendaraan bermotor roda dua-Standar Nasional Indonesia. Vol. 1811, SNI. Jakarta; 2007. p. 1-35.

20. Dewan Perwakilan Rakyat Republik Indonesia. Undang Undang Republik Indonesia Nomor 22 Tahun 2009 tentang Lalu Lintas dan Angkutan Jalan, 2009.

21. Kraus JF, Rice TM, Peek-Asa C, McArthur DL. Facial trauma and the risk of intracranial injury in motorcycle riders. Ann Emerg Med. 
2003;41(1):18-26.

22. Hitosugi M, Shigeta A, Takatsu A, Yokoyama T, Tokudome S. Analysis of fatal injuries to motorcyclists by helmet type. Am J Forensic Med Pathol.. 2004;25(2):125-8.

23. Bagheri SC, Dierks EJ, Kademani D, Holmgren E, Bell RB, Hommer L, et al. Application of a facial injury severity scale in craniomaxillofacial trauma. J Oral Maxillofac Surg. 2006;64:408-14.

24. Wang F, Huang X, Wen L, Gong J, Wang H, Li G, et al. Prognostic value of the Marshall computed tomography classification for traumatic subarachnoid hemorrhage. Asian Biomed. 2014;8(5):609-13.

25. Tanuhendrata A, Hatibie M, Oley M, Prasetyo E. Hubungan antara trauma kraniofasial dengan cedera kepala (Thesis). Manado: Universitas Sam Ratulangi; 2015.

26. Liu BC, Ivers $R$, Norton $R$, Boufous $S$, Blows S, Lo SK. Helmets for preventing injury in motorcycle riders. Cochrane Database of Syst Rev. 2008 Jan 23;(1):CD004333. doi: 10.1002/14651858.CD004333.pub3.

27. Komang A, Kalesaran L, Prasetyo E. Efektivitas penggunaan helm pada pengendara sepeda motor dalam pencegahan cedera kepala di RSU Prof. Dr. R.D. Kandou (Thesis). Manado: Universitas Sam Ratulangi; 2004.

28. Erdogan MO, Sogut O, Colak S, Ayhan H, Afacan MA, Satilmis D. Roles of motorcycle type and protective clothing in motorcycle crash injuries. Emerg Med Int. 2013;2013:760205.

29. Peek-Asa C, Mcarthur DL, Kraus JF. The prevalence of non-standard helmet use and head injuries among motorcycle riders. Accid Anal Prev 1999;31(3):229-33.

30. Houston DJ. Are helmet laws protecting young motorcyclists? J Safety Res. 2007;38(3):329-36.

31. Sung KM, Noble J, Kim SC, Jeon HJ, Kim JY, Do HH, et al. The preventive effect of head injury by helmet type in motorcycle crashes: A rural Korean single-center observational study. Biomed Res Int. 2016;2016:1-7.
32. Tsui CK, Rice TM, Pande S. Predictors of nonstandard helmet use among San Francisco Bay - Area motorcyclists. Traffic Inj Prev. 2014;15(2):151-5.

33. Bogerd CP, Rossi RM, Brühwiler PA. Thermal perception of ventilation changes in full-face motorcycle helmets: Subject and manikin study. Ann Occup Hyg. 2011;55(2):192-201.

34. Ramli R, Oxley J. Motorcycle helmet fixation status is more crucial than helmet type in providing protection to the head. Injury. 2016;47(11):2442-9.

35. Kulanthayan S, Radin URS, Ahmad HH, Mohd NMT, Harwant S. Compliance of proper safety helmet usage in motorcyclists. Med J Malaysia. 2000;55(2):40-4.

36. Thai KT, McIntosh AS, Pang TY. Factors affecting motorcycle helmet use: size selection, stability, and position. Traffic Inj Prev. 2015;16(3):276-82.

37. Shuaeib FM, Hamouda AMS, Radin URS, Hamdan MM, Hashmi MSJ. Motorcycle helmet - Part I. Biomechanics and computational issues. J Mater Process Technol. 2002;123(3):406-21.

38. Ramli R, Oxley J, Hillard P, Sadullah MA, McClure R. The effect of motorcycle helmet type, components and fixation status on facial injury in Klang Valley, Malaysia: a case control study. BMC Emerg Med. 2014;14(1):17.

39. Rutledge R, Stutts J. The association of helmet use with the outcome of motorcycle crash injury when controlling for crash/injury severity. Accid Anal Prev. 1993;25(3):347-53.

40. Servadei F, Begliomini C, Gardini E, Giustini M, Taggi F, Kraus J. Effect of Italy's motorcycle helmet law on traumatic brain injuries. Inj Prev. 2003;9(3):257-60.

41. Erhardt T, Rice T, Troszak L, Zhu M. Motorcycle helmet type and the risk of head injury and neck injury during motorcycle collisions in California. Accid Anal Prev. 2016;86:23-8.

42. Lopes ACE, Nogueira AFP, Cristino-Filho G, Mont'Alverne Lopes-Filho A, De Almeida CP, Prado R, et al. How safe is your motorcycle helmet? J Oral Maxillofac Surg. 2014;72(3):542-9. 